\title{
Plus ça change?
}

\section{The winner of France's election will find scientists willing to support the right kind of reforms.}

$n$ France's presidential election, the first round of which will be held on 22 April with a run-off two weeks later, research and innovation have emerged as significant campaign issues, crystallizing public concern about the nation's competitiveness and global standing.

This election is an important one for science. Presidents of France can make a real difference: Charles de Gaulle helped to create France's world-beating nuclear, aerospace and transport industries through a united national research effort in the 1950s. François Mitterrand invested heavily in research after his election in 1981 and oversaw a resurgence of French science.

Can France's next president fill these shoes? To help find out, Nature asked the three leading candidates - conservative Nicolas Sarkozy, socialist Ségolène Royal and a centrist, François Bayrou — to present their own visions for the future (see page 847).

All three pledge substantial spending on research to reverse the cuts imposed during Jacques Chirac's term of office. Increased funding is not enough, however. The next president must support muchneeded, targeted reforms of the science system, which has resisted comprehensive reform efforts for more than two decades.

Under Chirac, successive conservative governments have unsuccessfully sought to impose ill-considered reform packages on scientists with little consultation. It hasn't helped that they have cut budgets at the same time. The French left has traditionally been more supportive of science, but has been unwilling to engage in the reforms that are needed to boost scientific performance.

The scientific community has already reached a broad consensus on the sort of reforms that are required (see page 850). A pragmatic restructuring of France's fragmented life-science research is a priority, for example. An upgrade of the science ministry from its current junior status, to put it on a par with agriculture, finance and foreign affairs, is another. Salary structures should be adjusted to enable French institutions to compete for international talent in areas such as information technology, and skilled immigrants should be welcomed, not discouraged.

\section{Learning from the past}

There is no real need for a vast national consultation exercise (a favoured French pursuit). France's next president, whoever it is, could use his or her post-election momentum to press forward with change. In doing so, the president should note the mistakes of the past: there has been a repetitive cycle whereby new governments announce sweeping reforms, scientists take to the streets to oppose them, and then stalemate sets in. France does not need a grandiose rearrangement of the deckchairs of its research administration; it needs pragmatic, well-targeted and sustained changes in areas such as recruitment policy and salary structures.

The scientific community, for its part, should do more to articulate reasonable concerns without falling into the trap of resisting all change, as some trade-union representatives have been inclined to do. Representatives of the community should reflect scientists' own hunger for steps that will nurture research excellence.

In our survey of the candidates' views, Sarkozy perhaps articulates the need for reform most clearly. He proposes the transformation of the research agencies - whose labs currently perform the majority of French research - into research councils that would fund labs within a powerful and autonomous university system.

Appealing as that sounds, it is essentially the same reform programme that Chirac and successive conservative governments supported but failed to implement. Many of Sarkozy's science advisers are familiar from earlier administrations. The campaign rhetoric of every conservative government over the past quarter-century has been to declare research a 'national priority', only to change its tune once elected. Chirac, for example, promised in 2002 that the "commitment to research must be historic", only to make harsh cuts that provoked historic street demonstrations.

\section{Shift in emphasis}

Bayrou is a relatively unknown quantity to the research community. In his responses to our questions, he avoids talk of wholesale change, promising instead that a cross-party, non-partisan consensus could be found on pragmatic improvements to the existing system. His comments strike the right tone, although it remains unclear how Bayrou's small centrist party could form a government.

Royal seems likely, at least, to keep her funding promises. She introduced science and education into the heart of her campaign, and her commitment to both seems genuine. The danger, as always with the left in France, is that she will baulk at any meaningful reform in the face of resistance from public-sector workers and the trade unions. Royal says she plans to replace France's aloof style of government with the pragmatic consensus-building associated with Scandinavia. Just what French research needs, perhaps - but easier said than done.

The realistic path forward for French science lies in a shift of emphasis and power away from the research organizations, such as the CNRS and INSERM, towards the universities. But that cannot occur overnight. France's universities need to be fixed, for a start. With a few exceptions, they are physically dilapidated, badly managed and host to nepotism. To transfer research to the universities in their current state would be a step backwards in terms of research excellence.

Researchers also accept the idea of a related move towards a dual system of government laboratories and competitive grants. The open question is how to do this, and how quickly. The National Research Agency (ANR), created under Chirac to distribute research funds on the basis of grant proposals, is a step in the right direction. But as a branch of the science ministry, it lacks the autonomy and authority of, say, the US National Science Foundation or Germany's DFG.

Priority should be given to reforms that will make the greatest impact. French science has great strengths, however: would-be reformers must be careful not to throw the baby out with the bathwater. 